\title{
DRIS Analysis Identifies a Common Potassium Imbalance in Sweetgum Plantations
}

\author{
M. D. Coleman, ${ }^{1, *}$ S. X. Chang, ${ }^{2}$ and D. J. Robison ${ }^{3}$ \\ ${ }^{1}$ USDA-Forest Service, Southern Research Station, New Ellenton, \\ South Carolina, USA \\ ${ }^{2}$ Centre for Enhanced Forest Management, Department of Renewable \\ Resources, University of Alberta, Edmonton, Alberta, Canada \\ ${ }^{3}$ Hardwood Research Cooperative, Department of Forestry, North \\ Carolina State University, Raleigh, North Carolina, USA
}

\begin{abstract}
DRIS (Diagnosis and Recommendation Integrated System) analysis was applied to fast-growing sweetgum (Liquidambar styraciflua L.) plantations in the southeast United States as a tool for nutrient diagnosis and fertilizer recommendations. First, standard foliar nutrient ratios for nitrogen $(\mathrm{N})$, phosphorus $(\mathrm{P})$, potassium $(\mathrm{K})$, calcium $(\mathrm{Ca})$, and magnesium $(\mathrm{Mg})$ were established using high-yield stands from a region-wide sweetgum
\end{abstract}

\footnotetext{
\#The submitted manuscript has been authored by a contractor of the U.S. Government. Accordingly, the U.S. Government retains a non-exclusive, royalty-free license to publish or reproduce the published form of this contribution, or allow others to do so, for U.S. Government purposes.

*Correspondence: M. D. Coleman, USDA-Forest Service, Savannah River, P.O. Box 700, New Ellenton, SC 29809, USA; Fax: (803) 725-1807; E-mail: mcoleman@ifx.net or mcoleman01@fs.fed.us.
}

1919

DOI: $10.1081 / \mathrm{CSS}-120023227$

Published by Marcel Dekker, Inc.
0010-3624 (Print); 1532-2416 (Online) www.dekker.com 
fertilization study. DRIS indices were then calculated for the low-yield stands in the same study and stands from four other studies to evaluate foliar nutritional characteristics. Low-yield stands showed strong negative $\mathrm{K}$ imbalance, indicating insufficient $\mathrm{K}$, but also showed strong positive $\mathrm{Mg}$ imbalance. Potassium imbalance was also observed in the other four data sets tested. DRIS analysis successfully identified the tendency for $\mathrm{K}$ insufficiency to increase from early to late in the growing season, probably due to $\mathrm{K}$ foliar leaching and low soil $\mathrm{K}$ supply. While insufficient $\mathrm{N}$ was common in all the stands tested, the DRIS analysis failed to identify any $\mathrm{P}$ imbalance. We recommend that $\mathrm{K}$ be applied in $\mathrm{N}: \mathrm{K}$ ratios less than one to correct $\mathrm{K}$ imbalance problems in the studied sweetgum plantations. Supraoptimal $\mathrm{Ca}$ and $\mathrm{Mg}$ levels are expected to decline once insufficient $\mathrm{N}$ and $\mathrm{K}$ are corrected. DRIS analysis provides the means for diagnosing nutrient imbalance and a potential basis for prescribing corrective amendments in sweetgum plantations.

Key Words: Forest fertilization; Nutrient diagnosis; Short rotation woody crops; Liquidambar styraciflua.

\section{INTRODUCTION}

Nutrient diagnostic techniques are needed to identify mineral nutrient requirements and to prescribe fertilizer amendments for plantation grown trees. ${ }^{[1]}$ Accurate fertilizer prescriptions allow managers to optimize forest nutrition, maximize growth and prevent adverse environmental impacts. Soil and plant analyses have been used to diagnose nutrient requirements in the past. Soil analysis has not proven to be reliable because of difficulties in identifying the portion of the soil nutrient pool available for plant uptake. ${ }^{[1,2]}$ Plant analysis has received more attention for diagnosing forest stand mineral nutrient requirements because it provides a direct measure of plant nutrient uptake rather than soil nutrient supply capacity. ${ }^{[3-5]}$ Foliage holds the greatest diagnostic potential of any plant tissue, due to the range of macro- and micronutrients required for photosynthetic gain. For example, foliage requires $\mathrm{N}$ for photosynthetic enzymes, $\mathrm{P}$ for energy storage compounds, and $\mathrm{K}$ for stomatal functioning. ${ }^{[6,7]}$

A number of factors affect foliar nutrient concentrations including plant genetics, season, crown class, canopy position, soil moisture, and soil nutrient availability. ${ }^{[5,8,9]}$ Some of the variation in these factors can be controlled by using standardized sampling procedures, increasing the likelihood that foliar nutrient levels can be used successfully to predict growth response to fertilization. However, $\mathrm{N}$ fertilization, for example, may cause positive or negative changes in foliar $\mathrm{N}$ concentrations or cause imbalance of other 
un-amended essential mineral nutrients. ${ }^{[10,11]}$ Decreased nutrient concentrations can be explained by dilution through greater growth, ${ }^{[12]}$ whereas increases in $\mathrm{N}$ suggest that sufficient $\mathrm{N}$ was added and it was limiting, or that some other factor limited growth causing acquired $\mathrm{N}$ to accumulate. Increased concentrations of un-amended nutrients suggest improved uptake capacity. For these reasons, recommendations for diagnosing mineral nutrient requirements frequently consider ratios for multiple nutrients. ${ }^{[3,5,9,12-14]}$

Despite the need to evaluate and interpret multiple nutrients in foliar samples, forest fertilization programs typically focus on $\mathrm{N}$ because it is often the most limiting nutrient. Actual nutritional needs may not be known, and in some cases far less $\mathrm{N}$ may give the same response if supplied with another nutrient element. Other nutrients are subsequently considered when there is little or no response to $\mathrm{N}$ or when increasing rates of $\mathrm{N}$ additions do not elicit plant responses. Clearly, it is important to seek optimal nutritional balance for maximum productivity ${ }^{[15]}$ and there are many examples of $\mathrm{N}$ fertilization alone being ineffective or synergized by other nutrient elements. ${ }^{[16-18]}$ Accurately prescribing fertilizer amendments to achieve optimal nutrition requires tools for diagnosing nutrient balance and selecting nutrient demand priorities. Although the importance of nutritional balance in tree crops has long been considered in forest nutrition, ${ }^{[5,9]}$ tools for diagnosing balance have not been well developed or adopted in forest nutrient management programs.

The Diagnosis and Recommendation Integrated System (DRIS) is a nutritional balance method that has been routinely used in annual agricultural crops $^{[19-21]}$ and has been successfully applied in forest plantation research. ${ }^{[22-}$

${ }^{25]}$ To use DRIS, standard nutrient ratios must be developed from field-derived databases containing both growth and multi-element mineral nutrient concentrations. ${ }^{[26]}$ In the current study we used existing growth and foliar nutrient data for plantation-grown sweetgum (Liquidambar styraciflua L.) to assess the sensitivity and potential utility of DRIS as a nutrient management tool.

\section{METHODS}

\section{Sources of Data for DRIS Analysis}

The data used in the current study came from the following five sources.

1. HRC RW-46: We used growth and nutrient concentration information from the North Carolina State University-Hardwood Research Cooperative (HRC) region-wide 46 (RW-46) sweetgum fertilization and liming trials. ${ }^{\text {[27] }}$ This study consisted of 15 trials established in 1994 and 1995 on a wide range of sites from Mississippi to North Carolina. Each trial consisted of five fertilizer 
treatments replicated three times. Each treatment received $50 \mathrm{~kg} \mathrm{Nha}^{-1}$ and $56 \mathrm{~kg} \mathrm{Pha}^{-1}$ as diammonium phosphate prior to planting. Treatment No. 1 received no additional soil amendments. Treatment Nos. 2-5 all received a preplant addition of dolomitic lime to bring the mineral soil surface horizon to pH 5.5. ${ }^{[27]}$ Treatment No. 3 also received $56 \mathrm{~kg} \mathrm{Nha}^{-1}$ and treatment No. 4 received $112 \mathrm{~kg} \mathrm{Nha}^{-1}$ as ammonium nitrate at the start of the second growing season. Treatment No. 5 received $112 \mathrm{~kg} \mathrm{Nha}^{-1}$ as ammonium nitrate and $168 \mathrm{~kg} \mathrm{Ca} \mathrm{ha}^{-1}, 112 \mathrm{~kg} \mathrm{Sha}^{-1}, 56 \mathrm{~kg} \mathrm{Mg} \mathrm{ha}^{-1}, 22 \mathrm{~kg} \mathrm{Fe} \mathrm{ha}^{-1}, 22 \mathrm{~kg} \mathrm{Mn} \mathrm{ha}^{-1}$, $8.4 \mathrm{~kg} \mathrm{Cuha}^{-1}, 8.4 \mathrm{~kg} \mathrm{Znha}^{-1}$, and $1.7 \mathrm{~kg} \mathrm{Bha}^{-1}$ at the start of the second growing season. At the Beaufort County North Carolina location, boiler ash was applied as an additional treatment.

Nutrient concentrations from foliage collected at the conclusion of the second growing season were used. Five upper-crown leaves were sampled during the latter half of August from 14 trees per plot ( 0.2 ha, 1,344 trees $\mathrm{ha}^{-1}$ ). Foliar $\mathrm{N}$ concentration was determined using a dry combustion method (Carlo-Erba model NA-1500). Samples were digested using concentrated nitric acid and $\mathrm{H}_{2} \mathrm{O}_{2}$ and analyzed for total $\mathrm{P}, \mathrm{K}, \mathrm{Ca}$, and $\mathrm{Mg}$ concentrations (ICP determination). The same analytical methods were applied to each of the following sample collections.

2. HRC individual tree fertilization: These samples were from an individual tree fertilization trial established on International Paper Company land in Brunswick County, North Carolina. ${ }^{[28]}$ The trial consisted of a completely randomized block design with three replicate blocks and three trees per treatment combination in each block. Sixty-three trees were selected in each block. They were separated by at least $3 \mathrm{~m}$ (plantation density 1,344 trees ha $^{-1}$ ). Treatment combinations applied to individual trees at the start of the second growing season included seven $\mathrm{N}$ levels $\left(0,56,112,168,224,280\right.$, and $336 \mathrm{~kg} \mathrm{Nha}^{-1}$ as $\left.\mathrm{NH}_{4} \mathrm{NO}_{3}\right)$ and three $\mathrm{P}$ levels $\left(0,28\right.$, and $56 \mathrm{~kg} \mathrm{Pha}^{-1}$ as TSP). Foliar samples were collected from the upper crown position in late September of the second growing season. For the purposes of this study, the P treatments were averaged within each $\mathrm{N}$ treatment because no response to $\mathrm{P}$ was observed.

3. Seasonal nutrient samples: Samples were collected periodically to assess seasonal nutrient concentration patterns. Samples were collected from the upper crown position in "Treatment No. 1" plots of the Gates County, North Carolina site of the HRC RW-46 study. In each of these three replicate plots, five leaves were periodically collected from nine trees to form a composite sample between late June and late October during the third and fifth growing seasons. ${ }^{[8]}$

4. Irrigated USDA Forest Service plantations: Sampled were collected from research plots $\left(0.22 \mathrm{ha}, 1,333\right.$ trees ha $\left.^{-1}\right)$ grown at the Savannah River Site, which is a National Environmental Research Park in Aiken, County, 
South Carolina, as part of a larger study on short rotation woody crops. ${ }^{[29]}$ Results reported here only included samples collected from plots containing first-year trees in the irrigated and fertilized treatment. Each week the plots received $3 \mathrm{~cm}$ irrigation water and $1.5 \mathrm{~kg} \mathrm{Nha}^{-1}$ in a 7-7-7 liquid fertilizer blend derived from ammonium nitrate, ammonium polyphosphate, potash and a micronutrient blend. Foliar samples were collected from the upper crown position from six central trees per plot in early July.

5. Mature USDA-Forest Service plantations: Also sampled were mature stand research plots which were established at the Savannah River Site in Aiken, County, South Carolina in 1981 and 1983 to test the effects of stock characteristics and stand establishment practices. The 1981 plantation contained ten, 2,508 $\mathrm{m}^{2}$ plots $\left(1,075\right.$ trees ha $\left.^{-1}\right)$ located on deep sand $(\mathrm{Bt}$ horizon at $137-206 \mathrm{~cm}$ depth), and the 1983 plantation contained twelve, $297 \mathrm{~m}^{2}$ plots $\left(1,075\right.$ trees ha $^{-1}$ ) located on shallow sand (Bt horizon at 15$25 \mathrm{~cm}$ depth). In early July 2000, we collected upper-sunlit foliage from 10 central trees per plot in the 1981 study and four central trees per plot in the 1983 study for nutrient analysis. Original treatments had minimal effect on stand performance; therefore, for the purposes of this paper, mean values were calculated using analyses of foliage from each of the original plots.

\section{Standard Nutrient Ratios}

Standard nutrient ratios for DRIS analysis are obtained by considering a large sample set representative of crop growth conditions. The HRC RW-46 data are suitable for identifying DRIS standard nutrient ratios because they include standardized measurements of stem growth and foliar nutrient concentration for trees grown under a broad range of conditions. Stem growth was measured after the second growing season at 15 study locations, for a total of 216 observation plots. Foliage was sampled according to a standard protocol and analyzed for five essential plant macronutrients $(\mathrm{N}, \mathrm{P}, \mathrm{K}, \mathrm{Ca}$, and $\mathrm{Mg}$ ). A high-yield subset of those plots with average annual root collar diameter growth equal to or greater than $2.3 \mathrm{~cm} \mathrm{yr}^{-1}\left(0.9 \mathrm{in} \mathrm{yr}^{-1}\right)$ was selected. This subset included $7 \%$ of all plots, and was comprised of plots from three of the 15 study locations; one in Gates County, North Carolina, and two in Perry Co., MS. The remaining plots were used as the low-yield subset. Foliar nutrient concentrations from the high-yield subset were used to calculate standard nutrient ratios, assuming that these plots had favorable nutritional balance. It was assumed that there might be other plots with similar nutritional status that, due to other stress factors, would not grow at the same 
rate as the high-yield subset. It was also assumed that no low-yield plots would have more favorable nutritional balance than high-yield plots.

Nutrient expressions were calculated for every nutrient-pair combination (e.g., N/P or $\mathrm{P} / \mathrm{N}$ or NP). For each combination, the expression with the greatest high-yield to low-yield variance ratio was selected, to achieve the greatest diagnostic sensitivity. ${ }^{[26]}$ In no case did the product (e.g., NP) have the greatest variance ratio; therefore, these expressions are referred to as standard nutrient ratios.

\section{DRIS Index Calculations}

Given standard nutrient ratios from the high-yield subset of trees, nutrient balance can be determined for tissue samples by calculating DRIS indices. Index values are calculated for each nutrient in the analysis using the following formulae $\mathrm{e}^{[22,26,30,31]}$ :

$$
\begin{aligned}
& N \text { index }=\frac{-f\left(\frac{P}{N}\right)-f\left(\frac{K}{N}\right)+f\left(\frac{N}{C a}\right)+f\left(\frac{N}{M g}\right)}{4} \\
& P \text { index }=\frac{f\left(\frac{P}{N}\right)-f\left(\frac{K}{P}\right)+f\left(\frac{P}{C a}\right)+f\left(\frac{P}{M g}\right)}{4} \\
& K \text { index }=\frac{f\left(\frac{K}{N}\right)+f\left(\frac{K}{P}\right)+f\left(\frac{K}{C a}\right)+f\left(\frac{K}{M g}\right)}{4} \\
& C a \text { index }=\frac{-f\left(\frac{N}{C a}\right)-f\left(\frac{P}{C a}\right)-f\left(\frac{K}{C a}\right)+f\left(\frac{C a}{M g}\right)}{4} \\
& M g \text { index }=\frac{-f\left(\frac{N}{M g}\right)-f\left(\frac{P}{M g}\right)-f\left(\frac{K}{M g}\right)-f\left(\frac{C a}{M g}\right)}{4}
\end{aligned}
$$

The functions $(f)$ in each expression are calculated, using $\mathrm{P} / \mathrm{N}$ as an example, from the sample nutrient value $(\mathrm{P} / \mathrm{N})$ and the standard nutrient ratios $(\mathrm{p} / \mathrm{n})$ in 
the following way:

$$
\begin{aligned}
& \text { if } \frac{P}{N} \geq \frac{p}{n} \text { then } \\
& f\left(\frac{P}{N}\right)=\left(\frac{\frac{P}{N}}{\frac{p}{n}}-1\right) \frac{10}{C V} \\
& \text { or if } \frac{P}{N}<\frac{p}{n} \text { then } \\
& f\left(\frac{P}{N}\right)=\left(1-\frac{\frac{p}{n}}{\frac{P}{N}}\right) \frac{10}{C V}
\end{aligned}
$$

where $\mathrm{CV}$ is the coefficient of variation for the high-yield subset $\left(\mathrm{CV}_{\mathrm{p} / \mathrm{n}}\right)$. In this manner, DRIS indices can range from positive to negative, with zero indicating nutrient balance.

\section{Application of DRIS Indices}

DRIS indices were calculated for all sample plots in the HRC RW-46 study and comparisons were made between low- and high-yield subsets. We also calculated the indices for data from the four other studies described above to evaluate the nutritional balance, predictive capacity and utility of the developed standard nutrient ratios.

\section{RESULTS AND DISCUSSION}

\section{Standard Nutrient Ratios}

Table 1 presents the standard nutrient ratios from the HRC RW-46 highyield subset of sweetgum and for other tree species reported in the literature. The sweetgum standard nutrient ratios determined here fall within the range of published standard nutrient ratios for a variety of woody plants. Notably, each of the sweetgum ratios containing $\mathrm{K}$ in the numerator is higher than the average for the other woody plants, suggesting that high-yield sweetgum has relatively high demand for $\mathrm{K}$. 
Table 1. Standard nutrient ratios means and coefficient of variation (CV) for the high-yield sweetgum subset calculated in the current study. Percent DRIS standard nutrient ratios for a range of woody species grown for forest and horticultural products are presented for comparison.

\begin{tabular}{|c|c|c|c|c|c|c|c|c|c|c|c|}
\hline & $\mathrm{P} / \mathrm{N}$ & $\mathrm{K} / \mathrm{N}$ & $\mathrm{N} / \mathrm{Ca}$ & $\mathrm{N} / \mathrm{Mg}$ & $\mathrm{K} / \mathrm{P}$ & $\mathrm{P} / \mathrm{Ca}$ & $\mathrm{P} / \mathrm{Mg}$ & $\mathrm{K} / \mathrm{Ca}$ & $\mathrm{K} / \mathrm{Mg}$ & $\mathrm{Ca} / \mathrm{Mg}$ & Cite \\
\hline Sweetgum & 0.09 & 0.63 & 1.80 & 10.42 & 7.66 & 0.37 & 0.88 & 2.78 & 6.55 & 2.37 & Current study \\
\hline $\mathrm{CV}$ & 32 & 22 & 7 & 15 & 29 & 20 & 23 & 27 & 26 & 8 & \\
\hline \multicolumn{12}{|c|}{ Angiosperm, forest products } \\
\hline Cottonwood & 0.15 & 0.70 & 3.17 & 14.81 & 4.66 & 0.48 & 2 & 2.20 & 10.31 & 4.72 & {$[22]$} \\
\hline Sugar maple & & 0.58 & 1.58 & & & 0.19 & 3 & 0.90 & 7.12 & 7.60 & [32] \\
\hline Teak & 0.08 & 0.59 & 3.33 & 9.48 & 7.25 & 0.27 & & & 5.38 & 2.78 & {$[23]$} \\
\hline \multicolumn{12}{|c|}{ Angiosperm, horticultural } \\
\hline Orange & 0.05 & 0.26 & 0.63 & 8.09 & 5.07 & 0.03 & 5 & 0.17 & 2.21 & 12.12 & {$[33]$} \\
\hline Lemon & 0.04 & 0.32 & 0.62 & 6.25 & 7.69 & 0.03 & 6 & 0.18 & 2.04 & 10.00 & [34] \\
\hline Pomegranate & 0.12 & 0.78 & 0.85 & 4.64 & 6.75 & 0.11 & 7 & 0.74 & 3.45 & 5.15 & {$[35]$} \\
\hline Apple & 0.09 & 0.58 & 1.44 & 7.40 & 6.67 & 0.12 & & 0.83 & 4.27 & 5.13 & [36] \\
\hline \multicolumn{12}{|c|}{ Gymnosperm, forest products } \\
\hline Loblolly pine & 0.09 & 0.36 & 6.29 & 12.35 & 3.87 & 0.59 & 9 & 2.25 & 4.44 & 1.94 & {$[24]$} \\
\hline Chinese-fir & 0.13 & 1.09 & 1.02 & 2.64 & 8.33 & 0.15 & & 1.20 & & & [25] \\
\hline \multicolumn{12}{|c|}{ Gymnosperm, horticultural } \\
\hline Fraser fir & 0.10 & 0.32 & 6.02 & 29.41 & 3.37 & 0.57 & 11 & & & & {$[37]$} \\
\hline Fraser fir & 0.09 & 0.38 & 6.85 & 29.41 & 4.17 & 0.62 & 12 & 2.56 & 10.99 & 4.13 & {$[38]$} \\
\hline Cypress & 0.23 & 0.70 & 3.23 & 9.88 & 2.97 & 0.68 & 2.21 & & 6.54 & 3.39 & [39] \\
\hline
\end{tabular}




\section{Comparison of HRC RW-46 High- and Low-Yield Subsets}

Table 2 presents statistics on the high- and low-yield subsets in the HRC RW-46 study. Although the high-yield subset may not represent sweetgum's true growth potential, it is distinct from the low-yield subset and high relative to other reports. ${ }^{[10,11,40-42]}$ Therefore, it can be assumed that the nutritional balance of high-yield plots represent favorable balance and their nutritional information can be used to develop standard nutrient ratios. Growth differences between the two subsets are expected because they were separated on that basis. All nutrient concentrations of the high-yield subset were equal to or slightly lower than that of the low-yield subset, except for K, which was $32 \%$ greater in high-yield trees. DRIS indices for the high-yield subset were in good balance, all being within \pm 10 index points of zero. Such favorable balance in the high-yield subset is expected because the standard nutrient ratios used in the analysis were derived from these data.

The $\mathrm{N}, \mathrm{P}$, and $\mathrm{Ca}$ indices for the low-yield trees were also in good balance relative to standard nutrient ratios. However, mean and minimum $\mathrm{K}$ index values for the low-yield trees showed a strongly negative imbalance. Similarly, the $\mathrm{Mg}$ index was high for the low-yield trees indicating supra-optimal $\mathrm{Mg}$ levels. This apparent $\mathrm{K}$ insufficiency may be a significant factor limiting growth in the low-yield trees. The excess $\mathrm{Mg}$ levels are supportive of the conclusion that the low-yield plots were not in nutritional balance relative to high-yield nutrient ratios. Antagonistic mechanisms between $\mathrm{K}$ and $\mathrm{Mg}$ foliar nutrition have been observed in broadleaf and coniferous species. ${ }^{[43-45]}$ Therefore, the excess $\mathrm{Mg}$ uptake and insufficient levels of $\mathrm{K}$ may represent an antagonistic relationship in low-yield, nutritionally imbalanced sweetgum.

The Balance Index in Table 2 is a measure of overall nutritional balance. To calculate Balance Index, the absolute value of each of the five nutrient indices was summed. Because the average individual nutrient index includes negative values and the average Balance Index does not, the sum of average individual indices does not equal the average Balance Index. A Balance Index greater than 50 indicates imbalance, which is derived from a five-nutrient analysis, each with a balance threshold of 10 index points. In the high-yield subset, only $13 \%$ of plots exceeded a Balance Index of 50, whereas in the low-yield subset $73 \%$ of the plots exceeded 50 , indicating the majority were nutritionally imbalanced. 
Table 2. Means, standard error of the mean (SEM), maximum and minimum of sweetgum growth, nutrient concentration and DRIS index values for plots included in the high- $(\mathrm{n}=15)$ and low-yield $(\mathrm{n}=201)$ subsets of HRC RW-46.

\begin{tabular}{|c|c|c|c|c|c|c|c|c|c|c|c|c|c|}
\hline & $\begin{array}{c}\text { Basal diameter } \\
\text { growth } \\
\left(\mathrm{cm} \mathrm{yr}^{-1}\right)\end{array}$ & $\begin{array}{l}\text { Height } \\
\text { growth } \\
\left(\mathrm{cm} \mathrm{yr}^{-1}\right)\end{array}$ & $\begin{array}{c}\mathrm{N} \\
(\%)\end{array}$ & $\begin{array}{c}\mathrm{P} \\
(\%)\end{array}$ & $\begin{array}{c}\mathrm{K} \\
(\%)\end{array}$ & $\begin{array}{l}\mathrm{Ca} \\
(\%)\end{array}$ & $\begin{array}{l}\mathrm{Mg} \\
(\%)\end{array}$ & $\begin{array}{c}\mathrm{N} \\
\text { index }^{\mathrm{a}}\end{array}$ & $\begin{array}{c}\mathrm{P} \\
\text { index }\end{array}$ & $\begin{array}{c}\mathrm{K} \\
\text { index }\end{array}$ & $\begin{array}{c}\mathrm{Ca} \\
\text { index }\end{array}$ & $\begin{array}{c}\mathrm{Mg} \\
\text { index }\end{array}$ & $\begin{array}{l}\text { Balance } \\
\text { index }^{b}\end{array}$ \\
\hline \multicolumn{14}{|c|}{ High yield $(\mathrm{n}=15)$} \\
\hline Mean & 2.4 & 99 & 1.80 & 0.16 & 1.12 & 0.42 & 0.18 & 0 & 0 & -2 & 1 & 1 & 33 \\
\hline SEM & 0.02 & 3 & 0.03 & 0.01 & 0.05 & 0.02 & 0.01 & 2 & 3 & 3 & 1 & 2 & 4 \\
\hline $\operatorname{Max}$ & 2.6 & 114 & 2.10 & 0.31 & 1.39 & 0.56 & 0.22 & 11 & 32 & 14 & 7 & 10 & 68 \\
\hline Min & 2.3 & 80 & 1.56 & 0.13 & 0.81 & 0.32 & 0.14 & -14 & -9 & -24 & -8 & -10 & 13 \\
\hline \multicolumn{14}{|c|}{ Low yield $(\mathrm{n}=201)$} \\
\hline Mean & 1.4 & 63 & 1.19 & 0.19 & 0.85 & 0.53 & 0.24 & 1 & 6 & -30 & 5 & 18 & 82 \\
\hline SEM & 0.12 & 5 & 0.06 & 0.01 & 0.05 & 0.03 & 0.02 & 3 & 3 & 7 & 4 & 6 & 14 \\
\hline $\operatorname{Max}$ & 2.3 & 121 & 2.55 & 0.32 & 1.36 & 1.13 & 0.54 & 28 & 41 & 10 & 50 & 107 & 351 \\
\hline Min & 0.2 & 19 & 1.19 & 0.11 & 0.45 & 0.34 & 0.14 & -40 & -21 & -153 & -22 & -21 & 14 \\
\hline
\end{tabular}

${ }^{a}$ Individual nutrient index values of zero are balanced. Values below -10 are considered sub-optimal and values over 10 are considered supra-optimal.

${ }^{\mathrm{b}}$ The balance index was calculated by summing absolute values for individual nutrient index. Values above 50 indicate imbalance. 


\section{Individual Tree Fertilization}

DRIS analysis results for the individual tree fertilization data are summarized in Table 3. DRIS indices for the control treatment indicate N, P and $\mathrm{Ca}$ are in good balance, $\mathrm{Mg}$ is supra-optimal and $\mathrm{K}$ is sub-optimal, suggesting $\mathrm{N}$ and $\mathrm{P}$ fertilization will not stimulate growth until the $\mathrm{K}$ imbalance is corrected. Indeed, no growth or P concentration differences were observed in response to $\mathrm{P}$ additions, suggesting adequate levels and no further accumulation of this nutrient. Greatest growth was observed at moderate levels of applied fertilizer $\mathrm{N}$, but the response was small and not statistically significant. These maximum growth values were similar to that of the highyield subset in the HRC RW-46. At higher $\mathrm{N}$ application rates, foliar $\mathrm{N}$ concentration tended to increase. The Balance Index showed improvement between the control and treated trees, but large imbalances relative to the standard nutrient ratios calculated from the high-yield HRC RW-46 data still persisted even after fertilization. The $\mathrm{N}$ index increased to supra-optimal as $\mathrm{N}$ fertilizer rate increased, but the added $\mathrm{N}$ did not stimulate growth. Phosphorus index values declined as $\mathrm{N}$ amendment increased, but they were near balance (i.e., within 10 index points of zero). However, $\mathrm{K}$ concentrations were insufficient and $\mathrm{K}$ index values were low, implying insufficient $\mathrm{K}$ may have limited the response to $\mathrm{N}$ and $\mathrm{P}$ amendments. The high $\mathrm{Mg}$ index values also suggest nutrient imbalance may have limited its use.

Some of the nutrient imbalance may have been due to the time of sample collection. We collected samples from the individual tree fertilization trial on 27 September. During the growing season, mobile nutrients such as N, P, and $\mathrm{K}$ are retranslocated or leached as leaves age, whereas immobile nutrients such as $\mathrm{Ca}$ tend to increase with the progression of the season. ${ }^{[44,46,47]}$

\section{Seasonal Effects on DRIS Indices}

To determine if the nutrient imbalance of the individual tree trial was due to seasonal variation, we calculated DRIS indices for seasonally collected sweetgum foliar nutrient data. Figure 1 presents the change in DRIS indices from late June to late October for two growing seasons. The $\mathrm{Ca}$ and $\mathrm{Mg}$ indices increased as the season progressed. Relative concentrations of $\mathrm{Ca}$ and $\mathrm{Mg}$ typically increase as leaves age during the growing season. The $\mathrm{P}$ index remained surprisingly constant, and $\mathrm{N}$ and $\mathrm{K}$ indices declined from early to late in the growing season. The $\mathrm{K}$ index showed the greatest change over time, declining more than 45 index units. Employing products (e.g., N.Ca) in calculating DRIS indices may minimize the tissue age effect but it will not 
Table 3. Growth, nutrient content and DRIS index values for individual trees fertilized with different $\mathrm{N}$ levels.

\begin{tabular}{|c|c|c|c|c|c|c|c|c|c|c|c|c|c|}
\hline $\begin{array}{l}\text { Fertilizer } \\
\mathrm{N} \\
\left(\mathrm{kg} \mathrm{ha}^{-1}\right)\end{array}$ & $\begin{array}{c}\text { Diameter } \\
\text { growth } \\
\left(\mathrm{cm} \mathrm{yr}^{-1}\right)\end{array}$ & $\begin{array}{l}\text { Height } \\
\text { growth } \\
\left(\mathrm{cm} \mathrm{yr}^{-1}\right)\end{array}$ & $\begin{array}{c}\mathrm{N} \\
(\%)\end{array}$ & $\begin{array}{l}\mathrm{P} \\
(\%)\end{array}$ & $\begin{array}{c}\mathrm{K} \\
(\%)\end{array}$ & $\begin{array}{l}\mathrm{Ca} \\
(\%)\end{array}$ & $\begin{array}{l}\mathrm{Mg} \\
(\%)\end{array}$ & $\begin{array}{c}\mathrm{N} \\
\text { index }\end{array}$ & $\begin{array}{c}P \\
\text { index }\end{array}$ & $\begin{array}{c}\mathrm{K} \\
\text { index }\end{array}$ & $\begin{array}{c}\mathrm{Ca} \\
\text { index }\end{array}$ & $\begin{array}{c}\mathrm{Mg} \\
\text { index }\end{array}$ & $\begin{array}{l}\text { Balance } \\
\text { index }\end{array}$ \\
\hline 0 & 2.0 & 45 & 1.97 & 0.23 & 0.60 & 0.56 & 0.39 & -6 & 14 & -75 & -9 & 75 & 181 \\
\hline 56 & 2.2 & 53 & 2.03 & 0.16 & 0.60 & 0.55 & 0.35 & 4 & -5 & -64 & -2 & 67 & 141 \\
\hline 112 & 2.3 & 52 & 2.24 & 0.16 & 0.65 & 0.52 & 0.33 & 15 & -7 & -55 & -9 & 56 & 141 \\
\hline 168 & 2.2 & 46 & 2.24 & 0.15 & 0.61 & 0.53 & 0.33 & 16 & -8 & -61 & -5 & 58 & 149 \\
\hline 224 & 2.3 & 45 & 2.21 & 0.15 & 0.63 & 0.51 & 0.33 & 14 & -7 & -56 & -9 & 58 & 144 \\
\hline 280 & 2.0 & 46 & 2.37 & 0.16 & 0.64 & 0.52 & 0.32 & 22 & -5 & -56 & -10 & 50 & 144 \\
\hline 336 & 2.0 & 41 & 2.32 & 0.15 & 0.60 & 0.49 & 0.32 & 22 & -9 & -61 & -11 & 58 & 161 \\
\hline
\end{tabular}

${ }^{\mathrm{a}, \mathrm{b}}$ See footnotes in Table 2 . 


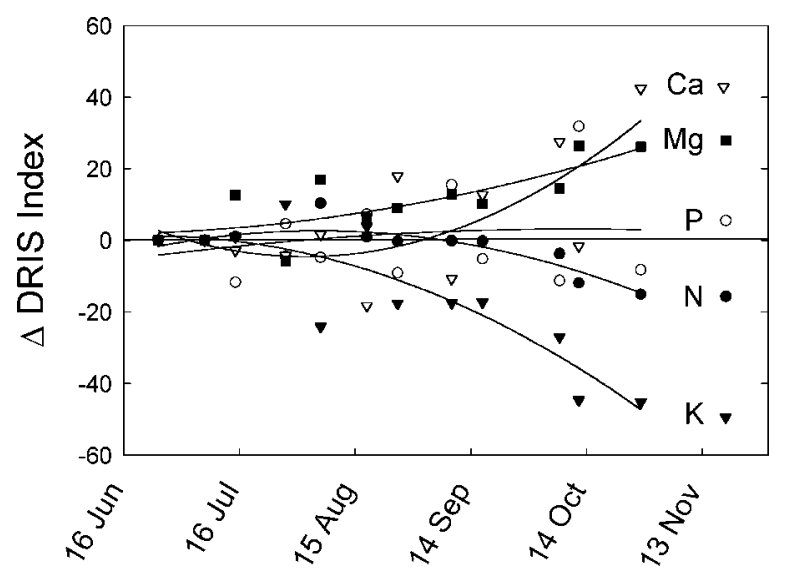

Figure 1. DRIS indices for seasonally sampled sweetgum foliage. Second order polynomial regressions plot the change of individual indices over time. Points show observations collected during two seasons from the HRC RW-46 Gates Country, North Carolina.

entirely eliminate seasonal effects. ${ }^{[48]}$ This confirms the importance of standardizing sampling dates for evaluating nutrient concentration, as is often called for in foliar analysis of forest trees. ${ }^{[8,9,13]}$ In this case, the most stable conditions occurred during mid-growing season.

The regression line fitted to the change in $\mathrm{K}$ index demonstrates that by 27 September, K was only 27 points below samples collected near 1 July. The individual tree fertilization samples collected on 27 September had K index values more than two times below the early season level. Therefore, even when accounting for seasonal patterns, the individual tree fertilization study shows a $\mathrm{K}$ imbalance.

\section{DRIS Comparisons Among Plantations}

Samples collected from the other sweetgum plantations also demonstrated nutritional imbalance relative to the high-yield HRC RW-46 subset (Fig. 2). The irrigated USDA Forest Service plantation had balanced or supraoptimal DRIS indices for all nutrients except K. Mature plantations located on deep and shallow sands were sub-optimal in both $\mathrm{N}$ and $\mathrm{K}$, while $\mathrm{P}$ was near balance and $\mathrm{Ca}$ and $\mathrm{Mg}$ were supra-optimal. The consistent sub-optimal $\mathrm{K}$ 


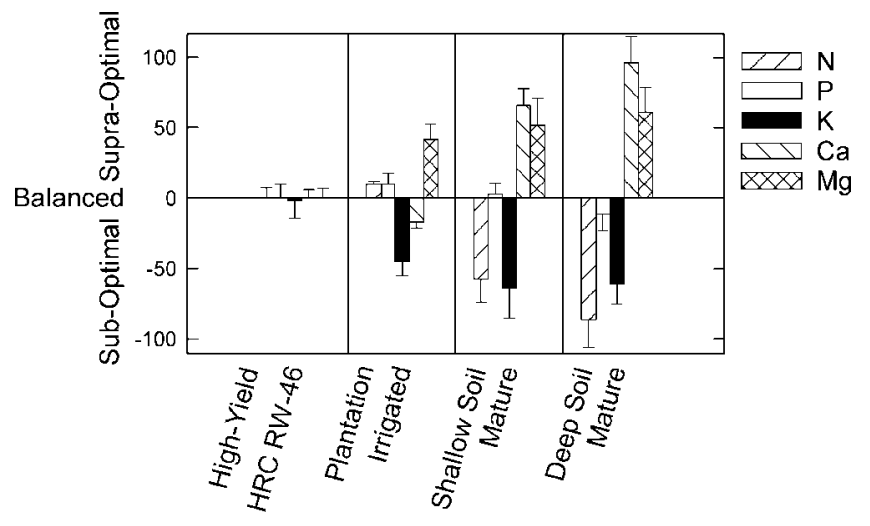

Figure 2. Comparison of high-yield DRIS indices compared with those of irrigated and mature sweetgum plantations. Bars show means of sample plots within each site \pm standard deviations.

index for sites tested suggests that insufficient $\mathrm{K}$ is common in sweetgum plantations in the southeast US.

Literature reports of sweetgum nutrient concentrations also show imbalanced nutrition compared to the high-yield standard nutrient ratios (Table 4). Nitrogen indices were commonly sub-optimal, $\mathrm{K}$ indices were always sub-optimal, while $\mathrm{Ca}$ and $\mathrm{Mg}$ indices were often supra-optimal. Cultural treatments such as weed control and $\mathrm{N}$ fertilization increased the $\mathrm{N}$ index in some situations, ${ }^{[10,11,40]}$ but DRIS indices indicate that $\mathrm{N}$ was commonly the second most limiting nutrient next to $\mathrm{K}$ as indicated by the ranking of indices. The $\mathrm{P}$ index was sub-optimal in two reports, ${ }^{[41,42]}$ but usually was close to balance or slightly positive. Phosphorus applications at the two sub-optimal locations would be expected to bring $\mathrm{P}$ index into balance. However, at both locations $\mathrm{N}$ and $\mathrm{K}$ ranked as higher application priorities than $\mathrm{P}$ because their indices were more negative than that of $\mathrm{P}$. The $\mathrm{Ca}$ and $\mathrm{Mg}$ indices were high probably due to adequate availability; however, it is likely that the trees lacked adequate growth to take advantage of that availability. Supplying sufficient amounts of sub-optimal nutrients (i.e., N and K) is expected to, first, satisfy the demand for these nutrients, and second, increase growth to take advantage of $\mathrm{Ca}$ and $\mathrm{Mg}$ availability. These mature tree examples support the idea that both $\mathrm{N}$ and $\mathrm{K}$ are typically limiting growth of sweetgum plantations. With very few exceptions, DRIS indices showed that $\mathrm{K}$ was in the greatest demand. 
Table 4. Growth and foliar nutrient concentrations reported for sweetgum plantations in the literature. DRIS indices were calculated from reported values using the standard nutrient ratios developed in the current study (Table 1).

\begin{tabular}{|c|c|c|c|c|c|c|c|c|c|c|c|c|}
\hline $\begin{array}{l}\text { Diameter growth } \\
\left(\mathrm{cm} \mathrm{yr}^{-1}\right)\end{array}$ & Treatment & $\begin{array}{l}\mathrm{N} \\
(\%)\end{array}$ & $\begin{array}{l}\mathrm{P} \\
(\%)\end{array}$ & $\begin{array}{c}\mathrm{K} \\
(\%)\end{array}$ & $\begin{array}{l}\mathrm{Ca} \\
(\%)\end{array}$ & $\begin{array}{l}\mathrm{Mg} \\
(\%)\end{array}$ & $\begin{array}{c}\mathrm{N} \\
\text { index }\end{array}$ & $\begin{array}{c}\mathrm{P} \\
\text { index }\end{array}$ & $\begin{array}{c}\mathrm{K} \\
\text { index }\end{array}$ & $\begin{array}{c}\mathrm{Ca} \\
\text { index }\end{array}$ & $\begin{array}{l}\mathrm{Mg} \\
\text { index }\end{array}$ & Citation \\
\hline 0.48 & Control & 1.70 & 0.31 & 0.68 & 0.89 & 0.30 & -19 & 31 & -71 & 35 & 24 & 40 \\
\hline 0.55 & Mow & 1.70 & 0.28 & 0.59 & 0.90 & 0.29 & -13 & 29 & -84 & 43 & 25 & \\
\hline 1.35 & Disk & 2.06 & 0.17 & 0.61 & 0.83 & 0.24 & 15 & -3 & -64 & 44 & 8 & \\
\hline 1.00 & & 1.09 & 0.19 & 0.93 & 1.79 & 0.42 & -86 & -29 & -59 & 119 & 56 & 41 \\
\hline 1.24 & $-\mathrm{N}^{\mathrm{a}}$ & 1.78 & 0.19 & 0.76 & 0.85 & 0.28 & -8 & -2 & -46 & 36 & 20 & 10 \\
\hline 1.57 & $+\mathrm{N}$ & 1.88 & 0.17 & 0.79 & 0.74 & 0.25 & 0 & -5 & -36 & 28 & 13 & \\
\hline- & $\begin{array}{l}\mathrm{U}-2 \\
\text { half-sib }\end{array}$ & 1.58 & 0.18 & 0.63 & 1.10 & 0.35 & -23 & -13 & -77 & 67 & 46 & 42 \\
\hline - & $\begin{array}{l}\text { A-3 } \\
\text { half-sib }\end{array}$ & 1.55 & 0.17 & 0.57 & 1.16 & 0.38 & -27 & -14 & -95 & 75 & 61 & \\
\hline 0.63 & $\begin{array}{l}\text { Non } \\
\quad \text { fertilized }\end{array}$ & 1.71 & 0.15 & 0.57 & 0.62 & 0.24 & 0 & -2 & -55 & 30 & 27 & 11 \\
\hline 0.67 & $\mathrm{~N}+\mathrm{P}$ & 2.10 & 0.15 & 0.62 & 0.53 & 0.21 & 20 & -1 & -45 & 13 & 13 & \\
\hline 0.83 & Complete & 2.12 & 0.16 & 0.63 & 0.58 & 0.22 & 19 & 0 & -48 & 16 & 13 & \\
\hline
\end{tabular}

${ }^{\text {a }}$ Sampled Sep 1975 (fourth season); fertilized in second and fourth seasons. 


\section{Testing DRIS Diagnostic and Prediction Capability in Sweetgum}

Nutrient imbalance identified by DRIS analysis assumes that the standard nutrient ratios are accurate estimates of optimal nutrient ratios. However, it is important to test the standard nutrient ratios and their prediction capability. Testing involves applying the insufficient nutrients identified by DRIS diagnosis to see if growth responds to improved nutritional balance.

For sweetgum plantations, amendments with $\mathrm{N}$ and $\mathrm{K}$ should be evaluated because of the widespread imbalanced diagnosed for both of those nutrients. To realize optimal growth, proportionally lower $\mathrm{N}$ may be required relative to $\mathrm{K}$, because $\mathrm{K}$ is diagnosed as the most limiting at many sites. Mewborn ${ }^{[11]}$ reported a significant sweetgum diameter growth response to a complete fertilizer blend including $\mathrm{K}$, compared with controls or $\mathrm{N}+\mathrm{P}$ fertilization alone (Table 4). However, this response was masked when volume and biomass were calculated using height and diameter data. It is important to note that she applied a relatively high amount of $\mathrm{N}$ to $\mathrm{K}(4: 1 \mathrm{~N}: \mathrm{K})$ in the complete fertilizer treatment. DRIS indices calculated from nutrient concentrations in her non-fertilized plots showed a greater requirement for $\mathrm{K}$ than for $\mathrm{N}$ (Table 4), and this imbalance persisted even after complete amendments were applied. Had nutrient amendments contained more $\mathrm{K}$ than $\mathrm{N}$, an improved $\mathrm{K}$ index and growth would have been expected.

A complete fertilizer blend with $\mathrm{K}$ was also applied as a treatment in the HRC RW-46 study. ${ }^{[27]}$ The complete fertilizer treatment improved the $\mathrm{K}$ index value, but again the amount applied $(1: 1 \mathrm{~N}: \mathrm{K})$ was not adequate to bring $\mathrm{K}$ into balance. For the low yield subset the complete treatment increased average $\mathrm{K}$ index from -34 to -16 , while the $\mathrm{N}$ index remained balanced, and growth increased from 1.38 to $1.48 \mathrm{~cm} \mathrm{yr}^{-1}$. We suspect a greater growth response would have been observed had a lower $\mathrm{N}: \mathrm{K}$ ratio been applied in the complete treatment. In another example, the fertilizer applied $(1.2: 1 \mathrm{~N}: \mathrm{K})$ in the Savannah River irrigation study was also inadequate to balance K nutrition (Fig. 2). It appears that amendments containing more $\mathrm{K}$ than $\mathrm{N}$ may be necessary to balance nutrition of these sweetgum plantations with $\mathrm{K}$ index values that are more negative than $\mathrm{N}$ index values, but this hypothesis needs to be tested, as other factors like temperature, soil moisture availability or pests may limit growth more than K supply.

The Beaufort County, North Carolina location of the HRC RW-46 study, which included study plots amended with boiler ash, provides a good opportunity to examine the probable effect of higher $\mathrm{K}$ supply rate on plantation growth and foliar nutrient balance. Boiler ash contains relatively high amounts of $\mathrm{K}$ and other essential plant nutrients, and can, 
therefore, serve to test our above hypothesis. Ash was applied in combination with a low $\mathrm{N}$ treatment $(1: 1.7 \mathrm{~N}: \mathrm{K})$ and the $\mathrm{K}$ index value improved from -28 to -10 . Growth increased more than $35 \%$ over the low $\mathrm{N}$ treatment alone (Table 5). In contrast, neither the high $\mathrm{N}$ treatment (without $\mathrm{K}$ addition), nor the complete fertilizer treatment $(1: 1 \mathrm{~N}: \mathrm{K})$ reached a growth rate as high as that of the ash treatment. These results suggest that $\mathrm{N}: \mathrm{K}$ application ratios below 1 will result in positive growth response if DRIS analyses indicate that $\mathrm{K}$ is the primary limiting nutrient. Although $\mathrm{N}$ is often deficient, other nutrients may be even more deficient; their availability must be improved before the maximum potential growth rate can be achieved through application of $\mathrm{N}$.

\section{CONCLUSIONS}

Standard nutrient ratios developed from the high-yield stands in the HRC RW-46 fertilizer study have provided the means to evaluate sweetgum nutritional balance with DRIS analysis. Several other plantations, with stands ranging from very young to mature, were also evaluated. The $\mathrm{N}$ and $\mathrm{P}$ concentrations were commonly low in these plantations, $\mathrm{Ca}$ and $\mathrm{Mg}$ were commonly high, but $\mathrm{K}$ was the primary nutrient required according to DRIS analysis. Potassium may be easily leached from the types of soils common to the sweetgum-growing region, resulting in growth-limiting conditions, especially on highly eroded agricultural soils where little topsoil remains. The wide site adaptability of sweetgum demonstrates that the species is capable of growth with sub-optimal K levels; however, the relatively high foliar K concentration in the high-yield subset suggests that adequate K supply is required for optimal growth.

Potassium should be provided in proportions exceeding $\mathrm{N}$ for plantations showing $\mathrm{K}$ as the primary limiting nutrient and $\mathrm{N}$ as the secondary limiting nutrient. We do not expect applications of N-only or fertilizers with high $\mathrm{N}: \mathrm{K}$ to alleviate insufficient $\mathrm{K}$ and maximize productivity. Correcting supraoptimal levels of $\mathrm{Mg}$ and $\mathrm{Ca}$ is expected to be an indirect result of satisfying insufficient $\mathrm{N}$ and $\mathrm{K}$. Alleviating $\mathrm{N}$ and $\mathrm{K}$ imbalance will result in improved growth, taking advantage of those elements already contained in supraoptimal concentrations.

The implications raised by these results require field-testing. It is possible that the standard nutrient ratios developed from the HRC RW-46 study are not representative of high productivity sweetgum; therefore, further testing of this approach is required. Two questions should be addressed in field trials: 
Table 5. Growth and foliar nutrient concentrations for the Beaufort County, North Carolina location of the HRC RW-46 study.

\begin{tabular}{llcccccccccc}
\hline $\begin{array}{l}\text { Diameter growth } \\
\left(\mathrm{cm} \mathrm{yr}^{-1}\right)\end{array}$ & Treatment & $\begin{array}{c}\mathrm{N} \\
(\%)\end{array}$ & $\begin{array}{c}\mathrm{P} \\
(\%)\end{array}$ & $\begin{array}{c}\mathrm{K} \\
(\%)\end{array}$ & $\begin{array}{l}\mathrm{Ca} \\
(\%)\end{array}$ & $\begin{array}{l}\mathrm{Mg} \\
(\%)\end{array}$ & $\mathrm{N}$ index & $\mathrm{P}$ index & $\mathrm{K}$ index & Ca index & Mg index \\
\hline 1.35 & Low N & 2.14 & 0.26 & 0.90 & 0.49 & 0.23 & 8 & 22 & -28 & -10 & 9 \\
1.83 & Low N w/ash & 2.09 & 0.22 & 1.10 & 0.49 & 0.19 & 7 & 13 & -10 & -3 & -7 \\
1.53 & Hi N & 2.13 & 0.22 & 0.85 & 0.43 & 0.22 & 10 & 16 & -26 & -14 & 15 \\
1.46 & Hi N complete & 2.05 & 0.22 & 1.01 & 0.44 & 0.22 & 4 & 14 & -15 & -13 & 10 \\
\hline
\end{tabular}


1) If DRIS analysis shows that $\mathrm{K}$ is required, can nutritional balance be achieved by applying nutrient amendments with an $\mathrm{N}$ to $\mathrm{K}$ ratio below one?

2) Will a positive growth response occur after nutritional balance is achieved in plots with negative $\mathrm{K}$ and/or $\mathrm{N}$ indices?

Affirmative answers to both these experimental questions will validate the use of DRIS for assessing sweetgum nutritional balance using the standard nutrient ratios from the HRC RW-46 high-yield plots.

\section{ACKNOWLEDGMENTS}

The Short Rotation Woody Crop Cooperative Research Project and the North Carolina State University Hardwood Research Cooperative provided support for this research. The Department of Energy-Savannah River Operations Office through the U.S. Forest Service Savannah River under Interagency Agreement DE-IA09-00SR22188 also provided support. Richard F. Fisher and Don Kaczmarek provided technical reviews.

\section{REFERENCES}

1. Binkley, D. Forest Nutrition Management; John Wiley \& Sons: New York, 1986; 290.

2. Walker, R.B.; Gessel, S.P. Mineral Deficiencies of Coastal Northwest Conifers; Institute of Forest Resources: Seattle, WA, 1991; Contribution No. 70, 63.

3. Ballard, T.M.; Carter, R.E. Evaluating Forest Stand Nutrient Status; British Columbia Ministry of Forests: Victoria, 1985; (Land Management Rept. 20), 60.

4. Morrison, I.K. Mineral Nutrition of Conifers with Special Reference to Nutrient Status Interpretation: A Review of Literature; Department of the Environment, Canadian Forest Service: Ottawa, 1974; Publ. 1343, 71.

5. Mead, D.J. Diagnosis of nutrient deficiencies in plantations. In Nutrition of Plantation Forests; Bowen, G.D., Nambiar, E.K.S., Eds.; Academic Press: London, 1984; 259-291.

6. Mengel, K.; Kirkby, E.A. Principles of Plant Nutrition, 3rd Ed.; International Potash Institute: Bern, 1982; 655.

7. Marschner, H. Mineral Nutrition of Higher Plants, 2nd Ed.; Academic Press: San Diego, 1995; 889. 
8. Chang, S.X.; Robison, D.J.; Young, M. Annual, seasonal and crown position variation in sweetgum foliar nutrients. In Proceedings of the Eleventh Biennial Southern Silvicultural Research Conference, GTRSRS, March 20-22, 2001, Knoxville, TN; USDA-Forest Service, Southern Research Station: Asheville, NC, 2001 (in press).

9. van den Driessche, R. Prediction of mineral nutrient status of trees by foliar analysis. Bot. Rev. 1974, 40, 347-394.

10. Nelson, L.E.; Switzer, G.L. Sweetgum half-sib seed source response to nitrogen and phosphorus fertilization in Mississippi. Soil Sci. Soc. Am. J. 1990, 54, 871-878.

11. Mewborn, B.M. Productivity, Leaf Area, and Nutritional Relationships in Mid-rotation Sweetgum and Sycamore Plantations. M.S. Thesis, North Carolina State University, Raleigh, NC, 1997, 77.

12. Leaf, A.L. Plant analysis as an aid in fertilizing forests. In Soil Testing and Plant Analysis; Walsh, L.M., Beaton, J.D., Eds.; Soil Science Society of America: Madison, WI, 1973; 427-454.

13. Weetman, G.F.; Wells, C.G. Plant analyses as an aid in fertilizing forests. In Soil Testing and Plant Analysis; Walsh, L.M., Beaton, J.D., Eds.; Soil Science Society of America: Madison, WI, 1990; 659-690.

14. Ericsson, T.; Rytter, L.; Linder, S. Nutritional dynamics and requirements of short rotation forests. In Ecophysiology of Short Rotation Forest Crops; Mitchell, C.P., Ford-Robertson, J.B., Hinckley, T., SennerbyForsse, L., Eds.; Elsevier Applied Science: London, 1992; 35-65.

15. Ingestad, T.; Lund, A.B. Theory and techniques for steady state mineral nutrition and growth of plants. Scand. J. For. Res. 1986, 1, 439-453.

16. Ponder, F. Fertilizer combinations benefit diameter growth of plantation black walnut. J. Plant Nutr. 1998, 21, 1329-1337.

17. van den Driessche, R.; Pondsford, D. Nitrogen induced potassium deficiency in white spruce (Picea glauca) and Engelmann spruce (Picea engelmannii) seedlings. Can. J. For. Res. 1995, 25, $1445-1454$.

18. Shepard, J.P.; Mitchell, M.J. Nutrient cycling in a red pine plantation thirty-nine years after potassium fertilization. Soil Sci. Soc. Am. J. 1990, $54,1433-1440$.

19. Walworth, J.L.; Sumner, M.E. Foliar diagnosis: a review. In Advances in Plant Nutrition; Tinker, B.P., Ed.; Elsevier: New York, 1986; Vol. III.

20. Anumdson, R.L.; Koehler, F.E. Utilization of DRIS for diagnosis of nutrient deficiencies in winter wheat. Agron. J. 1987, 79, 472-476. 
21. Hallmark, W.B.; Beverly, R.B.; deMooy, C.J.; Pesek, J. Relationship of diagnostic nutrient expression to soybean phosphorus and potassium diagnoses. Agron. J. 1991, 83, 858-863.

22. Leech, R.H.; Kim, Y.T. Foliar analysis and DRIS as a guide to fertilizer amendment in poplar plantations. For. Chron. 1981, 57, 17-21.

23. Drechsel, P.; Zech, W. DRIS evaluation of teak (Tectona grandis L.f.) mineral nutrition and effects of nutrition and site quality on teak growth in West Africa. For. Ecol. Manag. 1994, 70, 121-133.

24. Hockman, J.N.; Allen, H.L. Nutritional diagnoses in loblolly pine stands using a DRIS approach. Proceedings of the 7th North American forest soils conference. In Sustained Productivity of Forest Soils; Gessel, S.P., Lacate, D.S., Weetman, G.F., Powers, R.F., Eds.; University of British Columbia: Vancouver, 1990; 500-514.

25. Zhong, A.L.; Hsiung, W.Y. Evaluation and diagnosis of tree nutritional status in Chinese-fir [Cunninghamia lanceolata (Lamb) Hook] plantations, Jiangxi, China. For. Ecol. Manag. 1993, 62, 245-270.

26. Walworth, J.L.; Sumner, M.E. The diagnosis and recommendation integrated system (DRIS). Adv. Soil Sci. 1987, 6, 149-188.

27. Young, M.J.; Robison, D.J. Two-Year Growth, Foliar Nutrient and Leaf Area Responses of Sweetgum Plantations to Macro- and Micronutrients; Tech. Bull. P97-1; North Carolina State University: Raleigh, NC, 1997.

28. Anonymous. Individual tree sweetgum fertilization experiment. Hardwood Research Cooperative 37th Annual Report; North Carolina State University: Raleigh, NC, 2000; 34-37.

29. Coleman, M.D. Short rotation woody crops cooperative research program. In Proceedings of the Short Rotation Woody Crops Operations Working Group Third Biennial Conference, Syracuse, NY, October 10-13, 2000; Volk, T., Abrahamson, L., Eds.; SUNY Environmental School of Forestry: Syracuse, NY, 2001; 3-12.

30. Sumner, M.E. Preliminary N, P, and K foliar diagnostic norms for soybeans. Agron. J. 1977, 69, 226-230.

31. Schutz, C.J.; DeVilliers, J.M. Foliar diagnosis and fertilizer prescription in forestry: the DRIS system and its potential. In Forest Site Evaluation and Long-Term Productivity; Cole, D.W., Gessel, S.P., Eds.; University of Washington Press: Seattle, WA, 1988; 34-43.

32. Lozano, F.C.; Huynh, K.D. Foliar diagnosis of sugar maple decline by DRIS. Commun. Soil Sci. Plant Anal. 1989, 20, 1895-1914.

33. Beverly, R.B.; Stark, J.C.; Ojala, J.C.; Embleton, T.W. Nutrient diagnosis of 'Valencia' oranges by DRIS. J. Am. Soc. Hortic. Sci. 1984, $109,649-654$. 
34. Cerdá, A.; Nieves, M.; Martínez, V. An evaluation of mineral analysis of 'Verna' lemons by DRIS. Commun. Soil Sci. Plant Anal. 1995, 26, $1697-1707$.

35. Raghupathi, H.B.; Bhargava, B.S. Diagnosis of nutrient imbalance in pomegranate by diagnosis and recommendation integrated system and compositional nutrient diagnosis. Commun. Soil Sci. Plant Anal. 1998, 29, 2881-2892.

36. Goh, K.M.; Malakouti, M.J. Preliminary nitrogen, phosphorus, potassium, calcium and magnesium DRIS norms and indices for apple orchards in Canterbury, New-Zealand. Commun. Soil Sci. Plant Anal. 1992, 23, 1371-1385.

37. Rathfon, R.A.; Burger, J.A. Diagnosis and recommendation integrated system (DRIS) nutrient norms for Fraser fir Christmas trees. For. Sci. 1991, 37, 998-1010.

38. Hockman, J.N.; Burger, J.A.; Smith, D.W. A DRIS application to Fraser fir Christmas trees. Commun. Soil Sci. Plant Anal. 1989, 20, 305-318.

39. Eymar, E.; Cadahia, C.; Sánchez, A. Foliar nutrient reference levels obtained in hydroponic cultures as preliminary norms for DRIS to fertigate conifers. Commun. Soil Sci. Plant Anal. 2001, 32, 267-282.

40. Kennedy, H.E. Hardwood growth and foliar nutrient concentrations best in clean cultivation treatments. For. Ecol. Manag. 1984, 8, 117-126.

41. Francis, J.K.; Baker, J.B. Potential for nutrient depletion by short rotation harvest of sweetgum. Soil Sci. Soc. Am. J. 1982, 46, 1116-1118.

42. Nelson, L.E.; Shelton, M.G.; Switzer, G.L. The influence of nitrogen applications on the resorption of foliar nutrients in sweetgum. Can. J. For. Res. 1995, 25, 298-306.

43. Diem, B.; Godbold, D.L. Potassium, calcium and magnesium antagonism in clones of Populus trichocarpa. Plant Soil 1993, 155/156, 411-414.

44. Chapin, F.S. The mineral nutrition of wild plants. Ann. Rev. Ecol. Syst. 1980, 11, 233-260.

45. Sun, O.J.; Payn, T.W. Magnesium nutrition and photosynthesis in Pinus radiata: clonal variation and influence of potassium. Tree Physiol. 1999, $19,535-540$.

46. Côté, B.; Vogel, C.S.; Dawson, J.O. Autumnal changes in tissue nitrogen of autumn olive, black alder and eastern cottonwood. Plant Soil 1989, $118,23-32$.

47. Mitchell, H.L. Trends in the nitrogen, phosphorus, potassium and calcium content of the leaves of some forest trees during the growing season. Black Rock For. Bull. 1936, 9, 135. 
48. Sumner, M.E. The use and misuse of the diagnosis and recommendation integrated system (DRIS) in foliar diagnosis. In Proceedings of the Symposium Monitoramento Nutricional para a Recomendaçao da Adubaçao de Culturas, Piracicaba-SP, Brasil, April 14-16, 1999; Associaçao Brasileira para Pesquisa da Potassa e do Fostafo: Piracicaba, SP, Brasil, 1999. 